\title{
Building the Treaty \#3 Nibi Declaration Using an Anishinaabe Methodology of Ceremony, Language and Engagement
}

\author{
Aimée Craft ${ }^{1, *}$ and Lucas King ${ }^{2, *}$ (D) \\ 1 Faculty of Law, University of Ottawa, Ottawa, ON K1N 6L5, Canada \\ 2 Territorial Planning Unit, Grand Council Treaty \#3, Kenora, ON P9N 3X7, Canada \\ * Correspondence: aimee.craft@uottawa.ca (A.C.); lucas.king@treaty3.ca (L.K.)
}

check for

updates

Citation: Craft, A.; King, L. Building the Treaty \#3 Nibi Declaration Using an Anishinaabe Methodology of Ceremony, Language and

Engagement. Water 2021, 13, 532.

https://doi.org/10.3390/w13040532

Academic Editor: Athanasios Loukas

Received: 17 December 2020

Accepted: 8 February 2021

Published: 18 February 2021

Publisher's Note: MDPI stays neutral with regard to jurisdictional claims in published maps and institutional affiliations.

Copyright: (c) 2021 by the authors. Licensee MDPI, Basel, Switzerland. This article is an open access article distributed under the terms and conditions of the Creative Commons Attribution (CC BY) license (https:/ / creativecommons.org/licenses/by/ $4.0 /)$.

\begin{abstract}
Ratified in 2019, the Nibi Declaration of Treaty \#3 voices the relationship with water (Nibi) and jurisdictional responsibility that all Anishinaabe citizens have within the Treaty \#3 territory. It affirms the responsibilities and relationships that others living within the territory should have with the water and ensures that the spirit of Nibi is central to decision-making and water governance. This article details the process of developing The Declaration, in accordance with the Treaty \#3 lawmaking process and, which was driven by women, in ceremony, with the help of Gitiizii m-inaanik, and with the input of The Nation as a whole. This process embodies nationhood, sovereignty, and Anishinaabe jurisdiction as it relates to the environment and water, in accordance with the Manito Aki Inakonigaawin (Mother Earth law). Every person has a relationship with water. The process of nurturing that relationship through the teachings exemplified in the implementation of The Declaration will provide clarity on the responsibilities and partnerships that must be developed to protect the water for future generations.
\end{abstract}

Keywords: indigenous water governance; indigenous laws; indigenous governance; indigenous methodology; Anishinaabe; Nibi

\section{Introduction}

This article details the process of developing the Nibi Declaration of Treaty \#3. From the initial discussions among The Women's Council, followed by the engagement of Gitiizii $m$-inaanik (elders) in the ceremonies and development of the drafts, to the regional and national engagements, culminating with the final ratification of the document (in written and oral form) by The Nation, the process was driven by women, in the ceremony, with participation with The Nation in ways that reflect the Treaty \#3 lawmaking process.

The Nibi Declaration voices the relationship with water and jurisdictional responsibility that all Anishinaabe citizens have within the territory. It also affirms the responsibilities and relationships that others living within the territory should have with the water in it. In many ways, and, including through the ceremonial and community engagement process, The Declaration is responsive to the water and its desire to be engaged with through the terms of The Declaration. The key pillars of the development of The Declaration were, therefore, the ceremonies and the engagement throughout the process. This mirrored the Treaty \#3 lawmaking process and included ratification through ceremony and by The Nation at The National Assembly in 2019.

Below, we situate the Nibi Declaration process as an affirmation of jurisdiction, based on Anishinaabe laws. Its purpose is to give effect to the Manito Aki Inakonigaawin (MAI or Mother Earth Law) and to help advance the watershed management planning in the Treaty \#3 territory.

The partnership between Decolonizing Water Governance [1], the Territorial Planning Unit (TPU) of Grand Council Treaty \#3 (GCT3) and The Women's Council illustrates the importance of grounding research in ceremony and the protocols of The Nation. The 
methodology was community-engaged and community-led through the conception of the research models and each phase of the collaboration. This approach was engaged in helping anchor the Anishinaabe jurisdiction, decolonize the processes of decision-making in relation to water, and re-center water relationships within the territory.

The consistent emphasis on language throughout the life of the project, its central importance in the ceremonial aspects of the development of The Declaration, the equally authoritative interpretation of the text in Anishinaabemowin and the ongoing discussions on the transmission of knowledge and future educational curricula exemplifies the important role that language has in both conceptualizing responsibility and articulating concepts through an Anishinaabe lens.

As essential as the building of The Declaration as a core policy document is the plan to implement the principles through sharing of information, intergenerational transmission, education, public engagement and action. For example, initiatives like a Nibi Declaration website (currently in development) with teachings, songs and other key information that is representative of the diversity of water relationships, teachings, language and songs throughout the Treaty \#3 territory will provide a repository of information and a platform for engagement.

In the concluding section, this article canvasses some of the short-, medium- and longer-term implications of The Declaration for The Nation, on water governance more generally, and on the development of policy, including the potential recognition in law (both western and Anishinaabe) of the agency and spiritedness. It also questions whether the framework of legal personhood of water (recognizing the inherent rights of the water itself) may apply in the Treaty 3 Anishinaabe context.

\section{The Women's Vision: The Importance of Stating the Relationship to Nibi through the Declaration}

Located in the land of rock and water (Anishinaabe aki or sometimes also known as the Canadian Shield), Treaty \#3 is host to an abundance of water-lakes, streams, rivers, springs, etc. The Treaty \#3 Anishinaabe territory spans 55,000 square miles between North Western Ontario and Eastern Manitoba. Treaty \#3 is home to 28 Anishinaabe First Nations communities with a total population of approximately 25,000. Since time immemorial, and through the exercise of sacred relationships and responsibilities, the Anishinaabe of the region has worked to protect and respect the water throughout the territory. Water is life [1], and it is the lifeblood of all of Creation. It is through this lens, anchored in Anishinaabe worldview, that the responsibilities and relationship to Nibi rest with The Anishinaabe Nation of Treaty \#3.

Early in the process, The Women's Council developed a statement of purpose for The Declaration project-Aaniin Wengi iji chi ge'wiin (Why are we doing this) [2].

This Nibi Declaration is about respect, love, and our sacred relationship with Nibi and the life that it brings. It is based on Gitiizii m-inaanik teachings about Nibi, aki/lands, other elements (including air and wind) and all of Creation. This knowledge will be preserved and shared through the declaration with our youth and future generations. Anishinaabe-ikwewag has a sacred responsibility to Nibi. This declaration will guide us in our relationship with Nibi so we can take action individually, in our communities and as a Nation to help ensure healthy, living Nibi for all of Creation.

Rich in timber, minerals and other natural bounties, natural resource extraction in the Treaty \#3 Territory began before the Treaty relationship with the Crown was confirmed in 1873. In 1997, The Anishinaabe Nation of Treaty \#3 ratified the Manito Aki Inakonigewin (Mother Earth law), the first written law of The Anishinaabe Nation. This overarching legislation outlines the principles that guide decision-making and consultation with respect to the development of natural resources within the Treaty \#3 territory. The Nation has affirmed its collective interest over the territory and has committed itself to uphold the sacred relationship to lands and waters in light of persistent economic and resource development pressures in the territory. 
Current projects within the territory include two active mines with increasing mining claims, a potential deep geological repository for nuclear waste, and ongoing and cumulative impacts, including deforestation, hydroelectric development, tourism and cottage development. The territory also has experienced historical water impacts, the scars of which continue to be felt today. For example, the mercury contamination of the English-Wabigoon River system; the damming of Lake of the Woods, Lac Seul and the Winnipeg River; and the Shoal Lake Aqueduct, which provides drinking water to the city of Winnipeg, each contribute to the cumulative impact on the waterscape.

The discourse in Canada has largely progressed to include references to various forms of traditional knowledge (TK) or Indigenous knowledge (IK) and the protection of Aboriginal rights with respect to environmental decision-making and impacts on the exercise of constitutionally protected rights. However, in practice, the implementation of such ideas has yet to be achieved in a meaningful way. Governments and industries struggle with the application of Indigenous knowledge and values to decision-making. Existing colonial and hierarchical structures based on capitalist values continue to dominate over Indigenous-led decision-making. Extraction and resource manipulation has had a direct negative impact on the exercise of inherent and treaty rights of The Anishinaabe Nation and those of other Indigenous peoples. Decision-making authority has been stripped from Anishinaabe, and decisions are made to capture a wide variety of interests, often privileging industry, tourism and recreational cottage use of the lands and waters over the interests and authority of the Indigenous peoples. The balancing of multiple (and at times conflicting) interests has resulted in the exclusion of the values and jurisdiction inherently held by The Anishinaabe Nation of Treaty \#3 and excluded The Nation from regulation and decision-making with respect to development and management throughout the Winnipeg River basin [3].

The Anishinaabe of Treaty \#3 is not waiting for external validation or recognition. However, The Nation continues to collaborate with others to realize their responsibilities relating to water [4]. The Nibi Declaration provides the vision for Grand Council Treaty \#3 to develop watershed management planning based on inherent jurisdiction and in order to reaffirm and assert Anishinaabe responsibilities as they relate to Nibi. It provides the foundation and brings forth the voice of The Anishinaabe Nation in relation to Nibi and the responsibilities and values that will guide the protection and respect of Nibi for the future.

\section{Planning for the Future-And for the Watershed}

In part, the Nibi Declaration was meant to provide a foundation for the development of a Watershed Management Plan for the Treaty \#3 territory. Rooted in the Anishinaabe Law of Manito Aki Inakonigaawin [5] and guided through the Nibi Declaration, the management planning is an exercise of nationhood, which ensures that the inclusion of Anishinaabe laws through the four-direction (North, East, South, West) governance model of The Nation (social, economic, cultural and environmental) [6]. The Declaration is an assertion of Anishinaabe Nibi inaakonigewin and responsibilities for ongoing water management and governance within Treaty \#3. It is connected to the MAI, which is the overarching legislation that guides the relationship with Mother Earth for The Nation and for those who are proposing to impact the lands and waters within the territory.

This watershed management planning process includes four pillars linked to The Declaration:

- Governance;

- Ceremony;

- Community-based monitoring; and

- Outreach/education [7].

Each of the four pillars of the Watershed Management Plan is interconnected, supporting each other and creating a holistic management model. With the guidance of the declaration, these pillars inform policy, engagement and decision-making in relation to water and all of Creation. The watershed management planning process guides the understanding of the past and present and helps map out future implications of resource 
development in Treaty \#3 through a community-driven process. Each pillar draws from the voice and understandings of The Anishinaabe Nation, as affirmed in The Declaration, and creates opportunities to work in partnership to protect and fulfill the responsibilities to Nibi.

Water governance in Canada lacks cohesion and effective coordination considering the various federal, provincial, municipal, and Indigenous environmental laws and regulations, along with the interests of multiple third-party stakeholders [8]. The jurisdictional fragmentation that occurs between the federal, provincial, municipal and Indigenous governments [8] often results in poor sharing of information and resources, a lack of cohesion in policies and programs, and difficulty implementing and monitoring a variety of different water programs and standards [9].

On the other hand, decentralization, if inclusive of governmental, Indigenous, and industry perspectives, allows for water policies and programs to be responsive and adaptive to local needs [9]. Inclusivity of and deference to Indigenous perspectives, ecological and environmental knowledge, and Indigenous laws allows for an equal role between governments and Indigenous Nations in water governance. The method of inclusion of Indigenous peoples is often through constitutionally mandated consultation; however, this is not an adequate method of responding to shared ecological governance and management $[10,11]$. Consultation does not engage consent or active participation in decision-making. Shared water governance, on the other hand, involves non-state actors in the decision-making process regarding water resource development and management [12]. In the case of Indigenous Nations, this engagement in decision-making takes place on the basis of inherent jurisdiction and Indigenous legal orders.

We suggest that Indigenous participation in decision-making (particularly through the optics of consultation) is not sufficient. Enabling decision-making authority as a recognition of Indigenous jurisdiction is recognizes Indigenous self-determination and environmental management [13]. Indigenous Nations are asserting jurisdiction and decision-making power over water and environmental concerns through measures such as the Nibi Declaration. The re-politicization of water governance reflects the rejection of state-imposed roles for Indigenous nations in environmental governance, particularly in the nature of management rather than governance. Water governance includes the "development and management of water resources and delivery of water services" through the political and administrative processes initiated by decision-makers [12]. The declaration, along with other jurisdictional assertions of Indigenous laws, affirms Indigenous jurisdiction over water governance and management [14].

Guiding the work of the TPU, both the MAI and Declaration provide the vision for watershed management planning for The Anishinaabe Nation. GCT3 and the TPU, with guidance from Gitizii m-inaanik, the MAI and the Nibi Declaration, will continue to work in partnership with people throughout the Territory in order to share the Anishinaabe worldview, laws and values. This broader mobilization of knowledge and ethic of the partnership will be essential to the development of policies and practices within the watershed that are respectful of all knowledge systems. It will also help fulfill common desires to work collectively to protect the water that flows through the Treaty \#3 Territory. Partnerships based on the MAI, The Declaration and Anishinaabe inaakonigewin will advance the recognition of Anishinaabe jurisdiction and governance as it relates to Nibi.

\section{Anishinaabe Nibi Inaakonigewin (Water Law)}

Anishinaabe inaakonigewin is generated from different sources, the understanding and application of, which is a lifelong practice requiring a progression through levels. Each level of law is part of a set of concentric circles sourced in spiritual law and dependent on each other for complete legal understanding (see Figure 1-Sources of Anishinaabe Inaakonigewin (law)). Humans observe the application of spiritual law in the natural environment, as applied by other beings in Creation. Customary law is based on spiritual and natural law. This involves accepting responsibility in relation to our relatives. 
Anishinaabe people learn from and have been shaped by their environment since being placed on the Earth by the Creator [15]. Anishinaabe inaakonigewin is centered on relationships, which are part of Creation and exist between all beings [16,17]. Anishinaabe people thus have responsibilities to themselves, others, the land, and all beings on the land [18]. It is structured relationally, based on relationships as opposed to rights and obligations. This is based on a system of generalized reciprocity, where beings have a responsibility to one another based on a variety of relationships that are intrinsically connected, reflecting kinships structures [17].

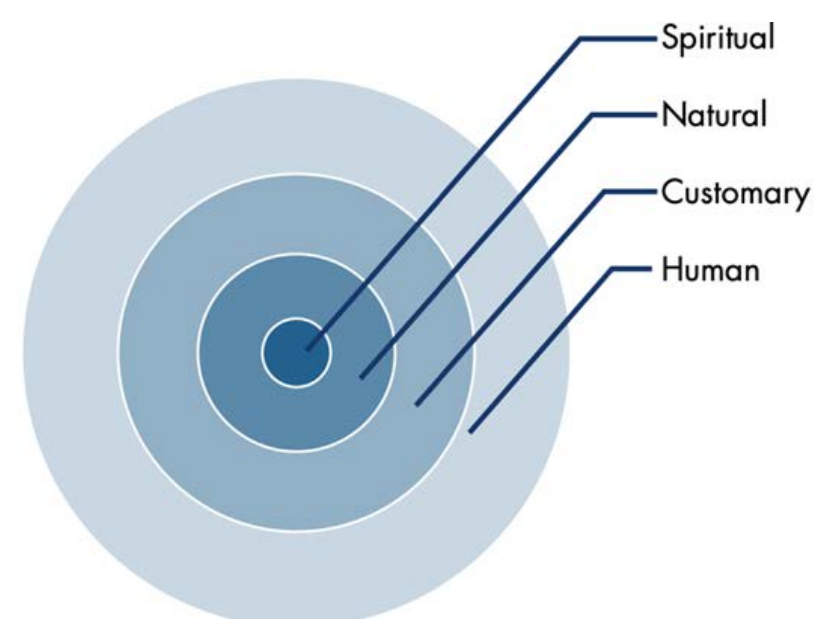

Figure 1. Sources of Anishinaabe Inaakonigewin (law) [19]. Copyright 2018 Centre for Institutional Governance Innovation.

Spiritual, natural, and customary law is applied to current relational contexts, with a fuller understanding of relationships and responsibilities. Together, these sources of law make up the principles by which interactions are governed among beings. As human beings, we then make laws (sometimes written in the form of legislation, Declarations, constitutions) to reflect these multilayered understandings of our legal obligations.

Anishinaabe Nibi inaakonigewin (water law) tells us that water is life-Nibi onje biimaadiiziizwin [20]. Water gives and takes life; we are born of water and are primarily composed of it. Our relationship with water is the most central and constant relationship in our human lifetime [21]. Water is also a living being, which relies on a web of relationships to be well and to bring wellness to other beings [20]. Humans also depend on relationships to live well (mino-biimaadiiziizin) [20]. Anishinaabe inaakonigewin requires that decision-making and actions be oriented toward mino-biimaadiiziwin. Mino-biimaadiiziwin is a foundational legal principle aimed at the well-being of all parts of Creation, including future generations [22]. Sacred creation stories remind us that human beings were the last to be placed on the Earth and are the most dependent of all beings in Creation. The relationships we have with the land, water, other beings, and among ourselves are equally sacred [23], and these relationships develop a sense of our normative values and legal principles [15].

Nibi is treated as an actor in a relationship in inaakonigewin. Land and water are not starkly distinguished under Anishinaabe inaakonigewin; the two are connected and their jurisdictions complementary [19]. For example, creation stories teach that the land is our mother, and the rivers are her veins. In accordance with creation stories, the original mother is a spirited being, and relationships with her are the foundations of relationships within all Creation. Bodies of water or waterways are independent entities with spirits, who are looked after and acknowledged and named in ceremonies and prayer [19].

Women have a special and distinct relationship to water in many Indigenous cultures [24] This relationship is based on cultural beliefs, social practices, economic contexts, and women's role in reproduction [24]. Water is associated with birth [25-29] The waters of 
the womb sustain new life and transport it from the spirit world to the physical world [24]. Anishinaabe kweyag (women) maintain a special relationship of care with water as water carriers and keepers of sacred birth water. This inherent responsibility to act as keepers of the water has never been relinquished [30]. Women's powerful spiritual connection to water and the significant responsibilities of guarding and managing water sources go beyond the relationship of giving life: "Our relationship with water is not just about our relationship with giving life; it's a relationship based in thinking about how we live on the earth. That's really lifelong learning [24]."

Because of their ability to harbor and nurture new life, women have a special connection to the life force represented by water [24]. Anishinaabe kwewag (women) have a sacred responsibility to Nibi and should be included in all decision-making relating to Nibi. As water protectors, women's responsibilities are exercised on behalf of children and the generations to come $[16,17]$. These responsibilities and knowledge relating to water [24] are shared through teachings and stories [31]. Being on the land is an integral method of acquiring and sharing Indigenous knowledge-Indigenous law is taught on and with the land and water [32]. Water and rocks are sources for understanding legal principles, including relationships and responsibilities. They help us understand how we govern our interactions among ourselves and with water $[16,17]$.

Grandmothers teach that the waters of the Earth are the veins of Mother Earth [24].

"The Earth is said to be a woman. In this way, it is understood that woman preceded man on the Earth. She is called Mother Earth because from her come all living things. Water is her lifeblood. It flows through her, nourishes her, and purifies her [33]."

Water is alive, has consciousness, and is healing [24-27]. It is capable of establishing relationships with other life forms. The relationship between water within our bodies and the water in the environment serves as a reminder of how everything is connected and how life depends on these connections [24]. For example, disrespect for or carelessness in managing the relationship with water affects spiritual and community well-being and physical health [24]. The relationship between water and humans is thus responsive and reciprocal [24]. Water can be used to heal [24].

\section{The Process of Creating the Nibi Declaration}

As stated in the Nibi Declaration and illustrated throughout the entire process, Nibi is alive and has a spirit. This spirit and the relationship between Nibi and The Anishinaabe Nation of Treaty \#3 provided the guidance and foundation for the process of developing The Declaration. Key elements of the methodology included the co-development of the project and important roles for women, ceremony and language throughout each phase of the process. The approach sought to reflect the Treaty \#3 lawmaking process through ceremony and community feedback.

In the first phase of research, a plan, purpose and research approach was developed by The Women's Council (Isobel White, Priscilla Simard, Maggie Petiquan, Anita Collins and Rhonda Fischer, in collaboration with the Decolonizing Water and TPU technicians (Prof. Aimée Craft, Indigenous research and PI Decolonizing Water Governance, and Lucas King, Water Resources Specialist at GCT3, the authors of this article). The entire process was guided by the Treaty \#3 Women's Council in recognition of the sacred relationship and responsibility of Anishinaabe kwewag (women) as carriers of life and protectors of the water. The women performed a ceremony, and the water was petitioned by the women with aasema (tobacco), food and song. After canvassing multiple Declarations and other information about Anishinaabe law and water governance, The Women's Council and authors identified the statement of purpose identified above.

In the planning stages, The Women's Council reinforced the need for Nation-based engagement to engage all people in Treaty \#3 (Indigenous and non-Indigenous). A core set of Gitiizii m-inaanik was engaged in providing advice and ceremonial instruction along the way. 
In a second phase, core data were gathered, including transcripts of Gitiizii m-inaanik teachings relating to Nibi. Data were gathered from Grand Council Treaty \#3 database of engagement sessions, feedback and surveys related to Nibi and watershed management planning. Treaty \#3 Women's Council requested at Gathering of Treaty \#3 elders' guidance relating to the teachings and responsibilities to Nibi. All raw data remains with Grand Council Treaty \#3 and with Craft as principal investigator on the project, in accordance with Tri-Council Guidelines and the University of Ottawa research office ethics protocol relating to this research.

The analysis of the data was conducted using thematic content analysis methods. The primary data were coded and analyzed thematically, using Anishinaabe visual thematic organization techniques. This thematic organization was then validated by The Women's Council and Elders. The result of the analysis is represented throughout the Nibi Declaration and Toolkit.

From there, in phase 3, two draft Declarations were produced. These were discussed at a meeting with The Women's Council and Gitiizii m-inaanik.

At the direction of The Women's Council, the Gitiizii m-inaanik that were engaged reflected a balance of male and female, in recognition that female Gitiizii m-inaanik generally carry the knowledge and ceremonies relating to water, and the men are responsible for supporting them [24]. The Gitiizii m-inaanik provided the foundation for the process, as they are the sources of knowledge through their experiences and relationships. The Gitiizii $m$-inaanik provided teachings about community and relationships inclusive of the mental, physical and spiritual dimensions [24]. This source of guidance and education led to a community and nation-based engagement that was rooted in ceremony and principles of Anishinaabe inaakonigewin. One of the participants in this session, Ogichidaa (Grand Chief) Kavanaugh, drew a Thunderbird around the visual representation of the principles (as illustrated below in Figure 2). The re-drafted Declaration was then taken to ceremony and feasted.

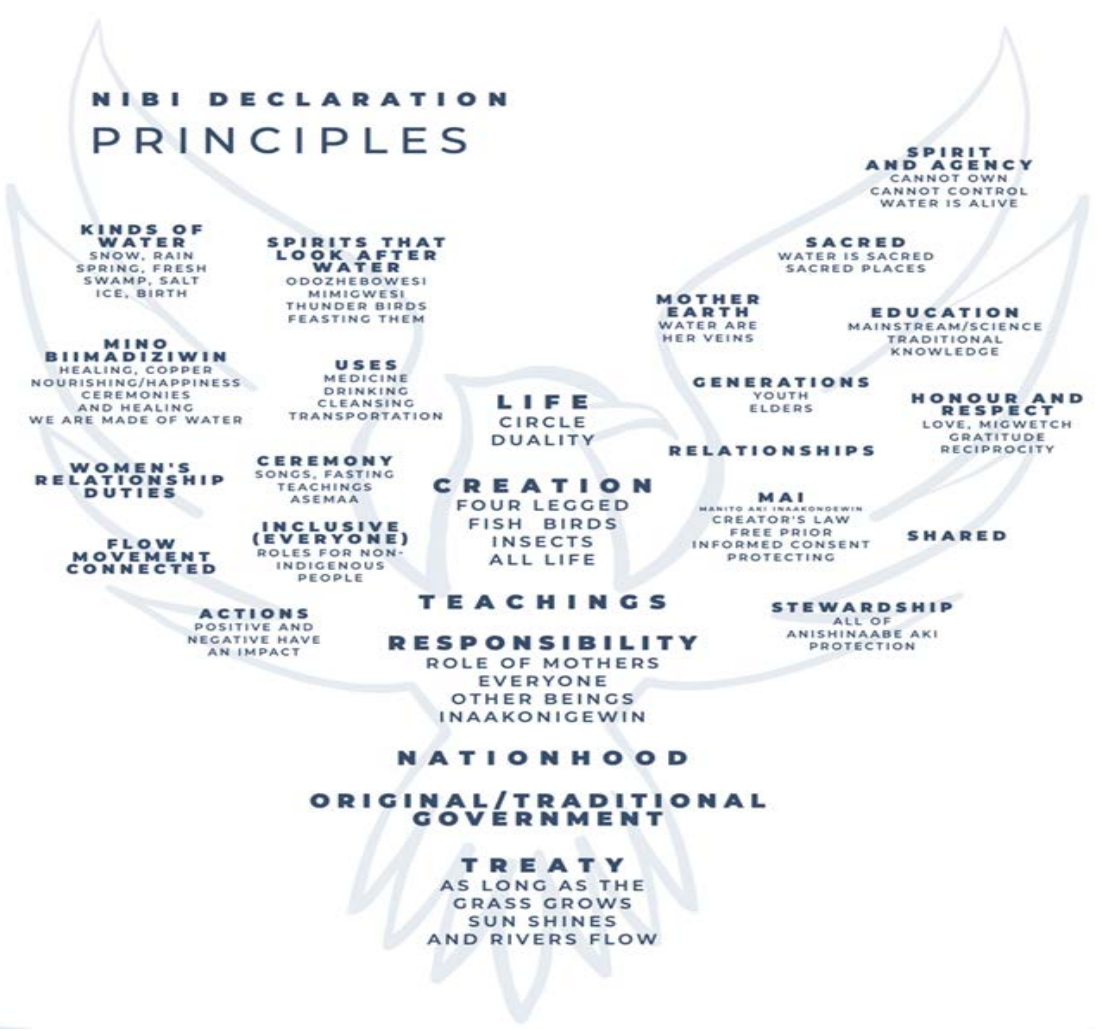

Figure 2. Nibi Declaration Principles [2]. Copyright 2020 NIBI. 
As identified in the early planning phases, the regional diversity of Treaty \#3 needed to be incorporated into The Declaration. In order to ensure that The Declaration truly reflected The Anishinaabe Nation, as a whole and in all its particularities, phase 4 (phases represented in Figure 3) of the process included a series of regional engagement sessions throughout the territory. This was meant to ensure that each of the Treaty \#3 regions (in the North, East, South, and West parts of the larger Treaty \#3 territory) were engaged (The four direction governance model of Grand Council Treaty \#3, is the practice of inherent self-governance, in which the right to make laws and policies exemplifies the jurisdiction of the nation). Ceremony, teachings and knowledge were shared by Gitizii m-inaanik throughout these regions, ensuring a community-driven research approach that was is reflective of The Anishinaabe Nation of Treaty \#3 4 direction governance model.

TIMELIN E O F

\section{THE NIBI DECLARATION}

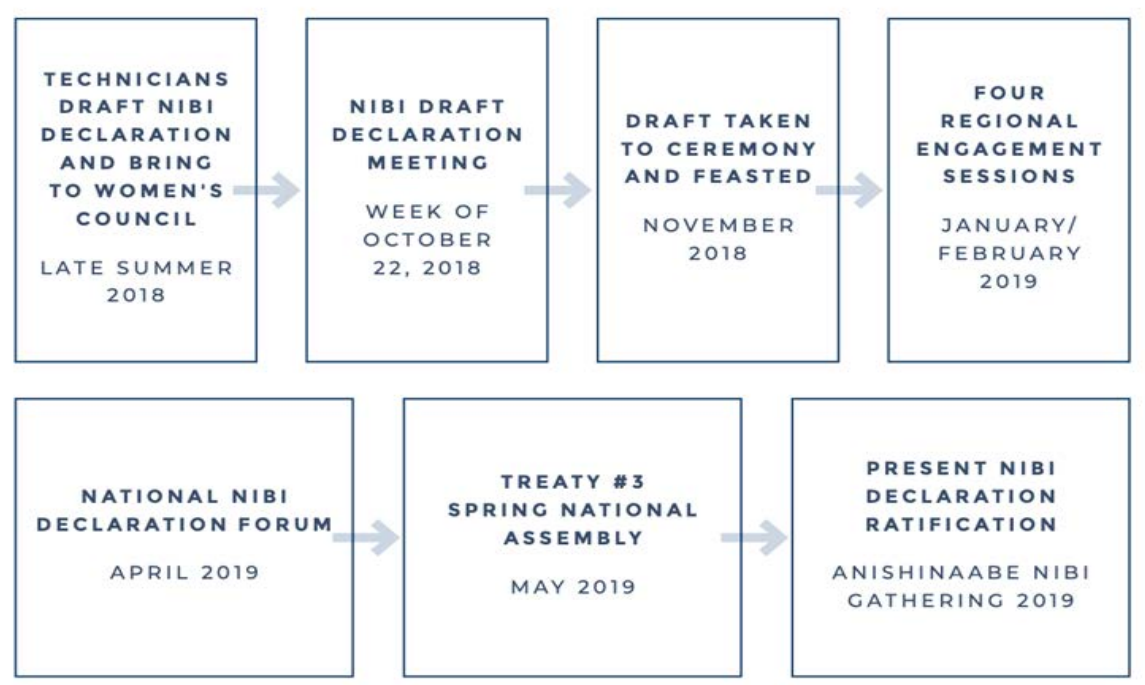

Figure 3. Timeline of the Nibi Declaration [2]. Copyright 2020 NIBI.

Technicians and members of The Women's Council facilitated sessions across the four regions of the Territory (Kenora (twice), Dryden, and Fort Frances). In each session, regional particularities (language, teachings, songs, etc.) were identified. An important piece of the regional diversity feedback was on the terms used to refer to water and types of water. Since language is central to Anishinaabe ways of knowing, the connection to oneself and teachings on how to live a good life [16,17], a decision was made to use the common term in Anishinaabemowin-Nibi-to reflect all forms of water.

The community engagements resulted in a third draft of The Declaration. In total, four drafts of the Nibi Declaration emerged through the guidance from Gitiizii m-inaanik, ceremony, and community engagement. These drafts, leading to the Nibi Declaration, also became the launching point for the visual representation of the sacred relationship between The Anishinaabe Nation and Nibi. Feedback from the regional engagement sessions led to the design of a logo that would represent The Declaration. Danielle Morrison, a visual artist from Treaty \#3, was commissioned. In her artist's statement, she explained:

The artwork, done in the Woodlands style of Treaty \#3, overall captures the essence of the interconnectedness between water, fish, animals, plants and finally, humans. There are two human figures, representing two generations and the responsibility we must protect water and life for the present and for the next generation. The duality of these figures also represents our responsibility; we must pass along the teachings of being a protector. Night and day are reflected in both the sun and the stars. Water in various forms is presented in 
a flowing river or body of water, the rain, and the snow. All of this embodied in a single drop of water, which can hold life, knowledge, and memory.

In the 5th phase, the fourth and final draft was presented at a National Assembly. Delegates from each of the 28 Nations were invited to attend, and funding was provided for travel for a woman, a youth and a Gitiizii m-inaanik. The big drum was present at the assembly, and ceremony was integral to the process. The Declaration was endorsed in the process, and additional suggestions were made for the implementation of The Declaration.

The Declaration was then presented, with the endorsement of The Nation at The National Assembly and Chiefs Assembly, representing the 6th phase of the process. In May of 2019, through ratification of a national record of decision, The Anishinaabe Nation of Treaty \#3 affirmed its sacred relationship with Nibi through the Treaty \#3 Nibi Declaration. The Declaration was interpreted in the Anishinaabemowiin language, as oral traditions remain important in the development of trust, information sharing and strategies [34]. The oral interpretation of The Declaration is maintained as an oral version of The Declaration and is equally authoritative to the written (English) version of the text because languages have a spirit that can be known through the people who understand them [35].

The Declaration and voice of The Nation were unanimously supported and were subsequently feasted and brought to the ceremony (phase 7), laying the foundation for the implementation of water governance in The Nation through a mirrored process to Treaty \#3 lawmaking.

In summary, the entire process, from start to finish, was guided by ceremony. Throughout the planning, The Women's Council and planning team were engaged in ceremony and made offerings to Nibi. The process for developing The Declaration was adaptive and, as a whole, mirrored as closely as possible the process and methods of the Treaty \#3 lawmaking processes. The Declaration was created through the affirmation of feedback provided at the community and regional level through a national forum, finally resulting in ratification [2]. This is an example of community-engaged research, based on Indigenous ways of knowing, developed through Indigenous world views, knowledge and experiences [36] in response to the direction provided by The Anishinaabe Nation of Treaty \#3.

Community driven research like the one used to develop the Nibi Declaration provide a framework of working together through Anishinaabe inaakonigewin principles and ensure respect for and guidance from the water throughout the process. Rather than being a subject of the research and Declaration, the water was a participant in the process, consistently being acknowledged and asked to participate in the activities. Nibi, Elders, Leaders and The Nation provided guidance throughout the process and researchers provided tools and mechanisms in order for this vision to be brought forward in The Declaration. In this style, the process remains adaptive and reflective of the partnerships developed and the guidance delivered through Nibi. The respect, trust and relationships developed between Nibi and all involved will propel Treaty \#3 Water governance forward with the spirit of Nibi and The Declaration as part of decision-making and the fulfillment of responsibilities to Nibi.

While in other contexts, Indigenous research (without the direct involvement and direction of Indigenous Nations) as scientific research implicated in colonialism remains a powerful remembered history for many colonized people [34], through communitydriven research, being adaptive to communities, ceremonies and knowledge of Gitiizii m-inaanik, the well-being of communities can be prioritized [37]. The process was built on the foundation of partnerships and trust. All participants were seen as helpers to the water; the relationships developed with The Nation and communities will continue to bring together a strong spiritual, ceremonial and cultural basis for the implementation of The Declaration. This process was rooted in ceremony, a defining feature of the communitydriven indigenous research process [38]. 


\section{Implementing the Declaration and Our Responsibilities to Nibi}

Implementation of the Nibi Declaration is a fluid, evolving process. The aim, similar to the methodology adopted for its development, is to engage, educate and share with all people, focus on intergenerational knowledge exchanges, and be responsive to water itself in order to fulfill the responsibilities in relation to water. This responsiveness to water creates a non-hierarchical process of knowledge exchange-where there is a flow back and forth between everyone involved, creating equitable space and exchanges between Gitiizii $m$-inaanik, knowledge keepers and academic researchers [36].

The connection to the life that water brings creates the fluid framework of implementation that ensure community needs and the responsibilities to water are fulfilled. Priorities for implementation of The Declaration were identified in both the regional engagements and National Forum and continue to be solicited in the work of the TPU and as part of the watershed management planning.

As affirmed in The Declaration, water unites us. Its flow and movement connect everyone within the Treaty \#3 territory as a life source and connection to the land. Educating all people about the sacredness of water and our sacred relationship with water is a core goal of the implementation of The Declaration. This will allow the sharing of Anishinaabe values and relationships with Indigenous and non-Indigenous peoples alike, create knowledge exchanges for the protection of water throughout the territory. As part of implementation priorities, intergenerational knowledge exchange opportunities should be fostered in order to have everyone within The Nation working to protect water in all its forms.

This includes awareness and support, and opportunities for knowledge exchange. These opportunities must address the physical, spiritual, and emotional lessons learned from and with Nibi. This may look different from many people looking to explore their own relationship with Nibi, and the educational opportunities will be provided to anyone who is willing to learn and to commit to the respect of Nibi and the core aspirations contained in The Declaration.

As part of the education strategy, various initiatives have been proposed, including distributing copies of The Declaration and posting them at key locations, such as public docks and marinas. In addition, signs will be erected in the territory, a website with key information will be developed, and opportunities for knowledge exchange (including a project relating to water songs) will be organized.

Nibi Declaration signs will be placed throughout the Treaty \#3 Territory. Starting with strategic locations at the entrance to the territory in all four directions, these signs will bring awareness of the sacred relationship between The Anishinaabe Nation and Nibi. The signs will outline the collective understanding of Nibi and how it should be treated, emphasizing the key themes of The Declaration:

Nibi has a spirit;

Nibi is life;

Nibi is sacred;

We honor, respect and love Nibi.

The Nibi/Water portal will be created to ensure resources are accessible to all and provided in mediums adaptive to Treaty \#3 youth. The portal will be an online resource that will mobilize knowledge generated from the Nibi Declaration project and the foundation it provides for future work. The portal will be comprised of videos, audio recordings, photographs and other engagements aimed at sharing knowledge about Nibi and particularly relating to language, songs and teachings.

The Nibi Nagamoon (water songs) project will bring together Anishinaabe knowledge keepers and youth for knowledge exchange about Nibi and particularly the songs that contain cultural and spiritual knowledge. This gathering will engage participants in the sharing of traditional teachings, relationships and experiences with Nibi that will explore normative values on the responsibilities and relationships held between The Anishinaabe Nation and Nibi. The values and teachings shared as part of this project will create resources 
to be shared on the Treaty \#3 water portal and continue to guide the implementation of The Declaration.

The Nibi Declaration Curriculum will be developed with the guidance and leadership of Anishinaabe Gitiizii m-inaanik, knowledge keepers and women. This will aim to provide resources to educators to mobilize data from the Nibi Declaration and the Portal, as well as other teachings that will support the and cultural retention of Nibi giikendaasowin (knowledge) and inaakonigewin (law).

One of the core themes of the Nibi Declaration of Treaty \#3 is that we all have a sacred relationship with Nibi, and with this relationship come responsibilities for the care and protection of water. The teachings and importance of these relationships, as outlined in the Nibi Declaration, form the foundation and core values on which governance and decisionmaking can take place. As The Declaration undertook a similar process of development as the Manito Aki Inakonigaawin (Treaty \#3 Great Earth Law, providing governance and guidance in relation to natural resource development and the environment), the two can provide support to one another in creating a mechanism for continued and reaffirmed Anishinaabe governance and jurisdiction in the Treaty \#3 territory.

The current approach at Grand Council Treaty \#3 relating to water governance is the watershed management planning and Watershed Model. The watershed model utilizes the vision of the Nibi Declaration to push forward initiatives in the categories of governance, ceremony, education and outreach, and community-based monitoring. Each of the four directions of the Treaty \#3 watershed model contributes to the overall implementation of the Nibi Declaration and to the assertion of Anishinaabe jurisdiction as it relates to MAI and the Nibi Declaration.

Another initiative at GCT3, the community-based Water Monitoring Program (CBM), contributes to governance and education. This CBM program is a partnership between GCT3 and Treaty \#3 communities in order to collect baseline water monitoring data across the territory. The purpose of this is to collect data across the territory on a continuous basis. The data will be used in part to evaluate the cumulative impacts experienced throughout the territory from historical natural resource development. This CBM program not only collects data but works with youth and communities to monitor certain factors of importance and bring opportunities for training through the International Institute for Sustainable Development-Experimental Lakes Area (IISD-ELA) to interested youth for an opportunity to learn from researchers, Gitiizii m-inaanik and the land. The data collected will be included in the Treaty \#3 geospatial database. This database will provide a centralized Treaty \#3 hub of information to evaluate and respond to initiatives and development in the Territory on a Nation scale. The database will also mobilize information and data by creating a centralized and confidential location for each Treaty \#3 Community to store their data (land use plans, values, interviews, etc.) and to choose to share these resources in accordance with the principles of Ownership, Control, Access and Possession (OCAP) [39]. This creates data sovereignty within The Nation, impacting the continued affirmation of self-governance and reliance on Treaty \#3 data, relationships, and values as they relate to decision-making surrounding water and the environment.

The International Joint Commission and Lake of the Woods Control Board are two examples of non-Indigenous governance structures that either manage or influence regulation throughout the Territory. With the guidance of the Nibi Declaration, partnerships and discussions are ongoing with both organizations; in order to centralize Nibi Inaakonigewin principles to water governance in Treaty \#3 as exemplified in The Declaration, there is much work still that needs to continue to move forward.

The assertion of Treaty \#3 jurisdiction in water governance is the affirmation and adhesion to Treaty \#3 processes that are rooted in ceremony and Anishinaabe Nibi inaakonigewin. Partnerships between Nations, adaptability and ensuring that community values and feedback are reflected in decision-making will help ensure the common objectives of protecting water. The principles described in the Nibi Declaration will be essential to good decisionmaking in the Treaty \#3 Territory. The Anishinaabe Nation of Treaty \#3 will be a leader in 
the stewardship and governance of Nibi throughout the Treaty \#3 territory and will help fulfill sacred relationships and responsibilities to protect water for future generations.

\section{In Conclusion: Thoughts towards the Future}

The Nibi Declaration reflects the voice and relationship of The Nation to Nibi and ensures that the spirit of Nibi is foundational to decision-making and water governance within the territory. Women have a sacred responsibility to water and a relationship to Creation because of their ability to give life. Therefore, the development of The Declaration, in accordance with the Treaty \#3 lawmaking process, was developed first by women, with the help of Gitizii m-inaanik, and with the input of The Nation as a whole through regional engagements and a National Forum.

Every being on this Earth has a relationship with Nibi accompanied by sets of responsibilities. The importance of ceremony and language in this relationship with Nibi can be better understood through The Declaration. The Declaration will continue to be an important reflection of the Anishinaabe worldview and laws for many years to come. While it is in written and oral form, with a visual representation, it will also evolve, in relation to the circumstances that present themselves, and parts of The Declaration may take more prominence at certain times to help deal with various aspects of governance and maintenance of the relationship with Nibi within the Treaty \#3 territory.

Creating the space for the spirit of Nibi in governance processes presents the opportunity for Nibi to guide protection on its own authority. This spiritual guidance from Nibi, coupled with the Gitiizii m-inaanik knowledge and ceremony, will provide the foundation for the continued affirmation of Nibi inaakonigewin (water law).

Most importantly, the Nibi Declaration reaffirms that Anishinaabe does not view water as a resource to be exploited, owned, consumed or commodified. Nibi is rather a living entity with its own agency and ability to govern itself. The relationship with Nibi is then required to be one of respect and deference. Anishinaabe inaakonigewin, planning and governance relating to Nibi is structured around this foundational principle.

The process undertaken during the Nibi Declaration reflects The Nationhood and sovereignty of The Anishinaabe Nation of Treaty \#3, which will continue to assert jurisdiction relating to the environment (MAI) and water (Nibi Declaration). This assertion of jurisdiction will address cumulative impacts to The Nation and concerns around increasing natural resource development. The MAI and the Nibi Declaration provide the legal and regulatory framework from an Anishinaabe legal perspective and engage the principles of decision-making relating to the territory.

The nation may also contemplate a written water law. It will also consider if the sacred relationship with water and the recognition of spiritedness and agency might be given effect through the recognition of legal personhood of water, or of Lake of the Woods, for example. Collaboration with international Indigenous partners is already underway to collectively discuss the merits of this approach. Personhood will be considered along with other mechanisms, rooted in Anishinaabe law and governance, that recognize and give effect to the spiritedness and agency of water and to help ensure its protection and future well-being. Future water governance issues in Treaty \#3 will be guided by the United Nations Declaration on the Rights of Indigenous Peoples, and particularly the right provided for in article 25 of Indigenous Nations to develop and maintain their spiritual relationships with water and to preserve that relationship for future generations [19].

The Declaration and the process undertaken to develop The Declaration provide a mechanism of intergenerational learning and represent an opportunity for future crosscultural and knowledge system learnings to encourage Anishinaabe and western knowledge systems to work together in order to protect water.

This research process was built collectively on the values, traditions and guidance of The Anishinaabe Nation of Treaty \#3 and can provide the framework and guidance for the present and future research projects that take place in the Territory. This approach can support stronger partnerships and connectivity between The Nation, communities 
and organizations to ensure water protection in the territory. The Declaration can help further understandings between Indigenous and non-Indigenous people as a foundation for continued dialog and potential partnerships. Water is our lifeblood and connects all Indigenous and non-Indigenous people. Every person has a relationship with water, and the process of nurturing that relationship through the teachings exemplified in the implementation of the Nibi Declaration will provide clarity on the responsibilities and partnerships that must be developed to protect the water for future generations.

The Anishinaabe Nation will continue to care for water and the spirit of Nibi through gatherings, water walks, and feasts. Each of these recognizing the importance and connection to Nibi and the water's ability to bring The Anishinaabe Nation and others together in order to care for and protect Nibi.

Author Contributions: Both A.C. and L.K. contributed evenly to the conceptualization, methodology, validation, analysis, investigation, writing, administration and funding acquisition of this research. Both authors have read and agreed to the published version of the manuscript.

Funding: "This research was funded by Social Sciences and Humanities Research Council of Canada, Partnership Engage Grants, Project Name: Manito Nibi- Grand Council Treaty \#3 Water Declaration Regional Consultations".

Institutional Review Board Statement: The Study was approved by University of British Columbia (Code: H16-01504) on 4 August 2016.

Informed Consent Statement: Informed consent was obtained from each participant that took part in the process.

Data Availability Statement: Data can be made available upon request from the Author's under OCAP principles. Data will only be available through written permission from the Anishinaabe Nation of Treaty \#3. Public data is available at: http://gct3.ca/land/territorial-planning-unit/ (accessed on 12 February 2021).

Acknowledgments: Grand Council Treaty \#3 Women's Council: Isobel White, Priscilla Simard, Maggie Petiquan, Anita Collins, Rhonda Fischer Gitiizii m-inaanik: Ida Skead, Gilbert Smith, Tommy White, Sherry Copenace, Allan White Oghichidaa: Francis Kavanaugh technical team: Aimée Craft (University of Ottawa, Decolonizing Water Governance), Lucas King (Grand Council Treaty \#3 Territorial Planning Unit). Student support: Alyssa Bird, Heather Gunter, Alexandra Machicado McGee, Justin Clory, and Ashley Wilson. A special acknowledgment is given to all those who worked on and contributed to the Manito Aki Inakonigaawin, the Anishinaabe Nibi Inaakonigewin Report, and Treaty \#3 Gitiizii m-inaanik Gatherings and to those who provided feedback on The Declaration and Toolkit in the regional engagement sessions and Nibi Forum.

Conflicts of Interest: The authors declare no conflict of interest.

\section{References}

1. A Social Sciences and Humanities Research Council Funded Partnership Grant. Available online: http:/ / decolonizingwater.ca (accessed on 12 February 2021).

2. Grand Council Treaty \#3, Nibi Declaration of Treaty \#3-Toolkit at 3, online (pdf): Grand Council Treaty \#3. Available online: http://gct3.ca/wp-content/uploads/2020/05/Nibi-Declaration-Toolkit-updated-May-2020.pdf (accessed on 12 February 2021).

3. Luby, B. Dammed: The Politics of Loss and Survival in Anishinaabe Territory; University of Manitoba Press: Winnipeg, MB, Canada, 2020.

4. McGregor, D. Traditional Knowledge and Water Governance: The ethic of responsibility. Altern. Int. J. Indig. Peoples 2014, 10, 493-507. [CrossRef]

5. Treaty \#3 Great Earth Law. See Grand Council Treaty \#3, Manito Aki Inakonigaawin (The Great Earth Law) online: Grand Council Treaty \#3. Available online: http:/ / gct3.ca/land/manito-aki-inakonigaawin/ (accessed on 12 February 2021).

6. Grand Council Treaty \#3, “Treaty \#3 Chiefs and Committees" online: Grand Council Treaty \#3. Available online: http:/ /gct3.ca/ our-nation/ (accessed on 12 February 2021).

7. Draft Grand Council Treaty \#3 Watershed Management Planning Model. Grand Council Treaty \#3, Territorial Planning Unit: Zhaagimaa Waabo online: Grand Council Treaty \#3. Available online: http://gct3.ca/land/territorial-planning-unit/ (accessed on 12 February 2021).

8. Renzetti, S.; Dupont, D.P. Water Policy and Governance in Canada; Springer: Cham, Switzerland, 2017. 
9. Bakker, K.; Cook, C.L. Water Governance in Canada: Innovation and Fragmentation. Int. J. Water Resour. Dev. 2011, 27, 275-289. [CrossRef]

10. International Joint Commission. Report to the Governments of the United States and Canada on Bi-National Water Management of the Lake of the Woods and Rainy River Watershed. 2012. Available online: https://www.ijc.org/sites/default/files/English-V 6-Web.pdf (accessed on 12 February 2021).

11. Nowlan, L. Customary Water Laws and Practices in Canada. Available online: http://www.fao.org/fileadmin/templates/legal /docs/CaseStudy_Canada.pdf (accessed on 12 February 2021).

12. Nowlan, L.; Bakker, K. Practising Shared Water Governance in Canada: A Primer; University of British Columbia: Vancouver, BC, Canada, 2010; Volume 8. Available online: http:/ / watergovernance.sites.olt.ubc.ca/files/2010/08/PractisingSharedWaterGove rnancePrimer_final1.pdf (accessed on 12 February 2021).

13. Bowie, R. Indigenous Self-Governance and the Deployment of Knowledge in Collaborative Environmental Management in Canada. J. Can. Stud. 2013, 47, 108. [CrossRef]

14. Curran, D. Indigenous Processes of Consent: Repoliticizing Water Governance through Legal Pluralism. Water 2019, $11,571$. [CrossRef]

15. Aimée, C. Giving and receiving life from Anishinaabe Nibi Innakonigewin (Our Water Law) research. In Methodological Challenges in Nature-Culture and Environmental History Research; Jocelyn, T., Stephanie, R., Anders, L.S., Eds.; Routledge: New York, NY, USA, 2016; p. 109.

16. Craft, A. Anishinaabe Nibi Inaakonigewin Report Winnipeg: Centre for Human Rights Research, Public Interest Law Centre, 2014 at 8, online (pdf). Available online: http:/ / create-h2o.ca/pages/annual_conference/presentations/2014/ANI_Gathering_R eport_-_June24.pdf (accessed on 12 February 2021).

17. Aimée, C. Breathing Life into the Stone Fort Treaty; UBC Press: Vancouver, BC, Canada, 2013.

18. Elder, M.D. Statement to the Truth and Reconciliation Commission of Canada. Truth and Reconciliation Commission of Canada. In Canada's Residential Schools: Reconciliation, The Final Report of the Truth and Reconciliation Commission of Canada; McGill-Queen's University Press: Montreal, QC, Canada, 2015; Volume 6, p. 5. Available online: http://www.trc.ca/assets/pdf/Volume_6_Rec onciliation_English_Web.pdf (accessed on 12 February 2021).

19. Aimée, C. UNDRIP Implementation: More Reflections on the Braiding of International, Domestic and Indigenous Laws; Centre for International Governance and Innovation: Waterloo, ON, Canada, 2018; p. 60.

20. Aimée, C. UNDRIP Implementation: More Reflections on the Braiding of International, Domestic and Indigenous Laws; Centre for International Governance and Innovation: Waterloo, ON, Canada, 2018; p. 56.

21. Aimée, C. UNDRIP Implementation: More Reflections on the Braiding of International, Domestic and Indigenous Laws; Centre for International Governance and Innovation: Waterloo, ON, Canada, 2018; p. 58.

22. Aimée, C. UNDRIP Implementation: More Reflections on the Braiding of International, Domestic and Indigenous Laws; Centre for International Governance and Innovation: Waterloo, ON, Canada, 2018; p. 61.

23. Wilson, S. Research is Ceremony: Indigenous Research Methods; Fernwood Publishing: Winnipeg, MB, Canada, 2008 ; p. 87.

24. Anderson, K.; Clow, B.; Haworth-Brockman, M. Carriers of Water: Aboriginal Women's Experiences, Relationships, and Reflections. J. Clean. Prod. 2013, 60, 11-17. [CrossRef]

25. Michael, B. Water: A first nations' spiritual and ecological perspective. BCJ 2001, 1. Ecosystems and Management. Available online: http:/ / citeseerx.ist.psu.edu/viewdoc/download?doi=10.1.1.513.7590\&rep=rep1\&type=pdf (accessed on 1 February 2021).

26. McGregor, D. "Anishnaabe-Kwe, Traditional Knowledge, and Water Protection” (2008) 26:3-4 Canadian Woman Studies. Available online: https:/ / cws.journals.yorku.ca/index.php/cws/article/view/22109/20763 (accessed on 1 February 2021).

27. McGregor, D. Water quality in the Province of Ontario: An Aboriginal Traditional Knowledge Perspective. In L'eau comme patrimoine: De la Méditerrainée à l'Amérique du Nord; Hermon, E., Ed.; Presses de l'Université: Laval, QC, Canada, 2008.

28. Chiefs of Ontario. Water Declaration of the First Nations in Ontario. 2008. Available online: https://www.afn.ca/uploads/files / water/08-10-00.pdf (accessed on 12 February 2021).

29. Sanderson, C.D. Nipiy Wasekimew Clear Water: The meaning of Water, from the Words of the Elders. Ph.D. Dissertation, Simon Fraser University, Burnaby, BC, Canada, 2008.

30. Wilson Danard, D. Be the Water-Reflections on Water, Climate and Humanity (Part 4) Canadian Women's Studies. 2015, 30. Available online: https://static1.squarespace.com/static/5b6b5d54fcf7fd941850673f/t/5e800432d5037c1157d61039/158544799 $1500 /$ Part+4+-+Be+the+Water+by+Debby+Danard.pdf (accessed on 1 February 2021).

31. Szach, N.J. Keepers of the Water: Exploring Anishinaabe and Métis Women's Knowledge of Water and Participation in Water Governance in Kenora, Ontario. Master Thesis, Natural Resources Management, University of Manitoba, Winnipeg, MB, Canada, 2013. Available online: https://www.umanitoba.ca/institutes/natural_resources/Left-Hand\%20Column/theses/Masters\%20 Thesis\%20Penneys-Szach\%202013.pdf (accessed on 12 February 2021).

32. Borrows, J. Law's Indigenous Ethics; University of Toronto Press: Toronto, ON, Canada, 2019; p. 152.

33. Benton-Banai, E. The Mishomis Book: The Voice of the Ojibway; University of Minnesota Press: Minneapolis, MN, USA, 2010.

34. Smith, L.T. Decolonizing Methodologies: Research and Indigenous Peoples; Zed Books: New York, NY, USA, 2012.

35. Battiste, M. Research Ethics for Protecting Indigenous Knowledge and Heritage: Institutional and Researcher Responsibilities. In Handbook of Critical and Indigenous Methodologies Sage; Denzin, N.K., Yvonna, S.L., Smith, L.T., Eds.; University of Saskatchewan: Thousand Oaks, CA, USA, 2008. 
36. Arsenault, R.; Diver, S.; McGregor, D.; Witham, A.; Bourassa, C. Shifting the Framework of Canadian Water Governance through Indigenous Research Methods: Acknowledging the Past with an Eye on the Future. Water 2018, 10, 49. [CrossRef]

37. Office of Community-University Engagement, University of Victoria. "Community-Engaged Research" (2017) online (pdf). Available online: https://www.uvic.ca/cue/assets/docs/CER_KeyAspectsvV1.1.pdf (accessed on 12 February 2021).

38. Hart, M.A. For Indigenous Peoples, By Indigenous Peoples, With Indigenous Peoples: Towards an Indigenous Research Paradigm in Wícihitowin: Aboriginal Social Work in Canada; Sinclair, R., Hart, M.A., Bruyere, G., Eds.; Fernwood Publishing: Winnipeg, MB, Canada, 2009.

39. First Nations Information Governance Centre. The First Nations Principles of OCAP ${ }^{\circledR}$ online: First Nations Information Governance Centre. Available online: https:/ / fnigc.ca/ocap-training/ (accessed on 12 February 2021). 